\title{
SELF-FERTILISATION IN MALE-FERTILE PLANTS OF A GYNODIOECIOUS SPECIES: THYMUS VULGARIS L.
}

\author{
G. VALDEYRON, B. DOMMÉE and Ph. VERNET \\ Laboratoire de Génétique ecologique du Centre d'etudes phytosociologiques et \\ ecologiques Louis Emberger. (Post address: C.N.R.S., BP. 5051, 34033 \\ Montpellier Cedex, France)
}

Received 18.iii.77

\section{Summary}

To determine the rate of self-fertilisation in male-fertile plants of thyme, four populations, homozygous for dominant chemical marker alleles, were chosen. Male-sterile plants and male-fertile plants with the corresponding recessive marker alleles were transplanted into these populations and the seedlings obtained by growing the seeds gathered in 1974 and 1975 from these test plants were analysed.

An appreciable rate of self-fertilisation has been found in the four populations $(0.36,0.49,0.35$ and 0.10$)$ but the individual test plants give highly variable results (from 0 to $0 \cdot 79$ ). The figures were rather consistent from one year to the next. An important part of the variation in self-fertilisation may be ascribed to differences in the densities of local male-fertile plants in the first few metres around the test plants.

\section{INTRODUCTION}

Thymus vulgaris L. (Labiatae), or common thyme, is a wild plant of the Mediterranean flora. The species is gynodioecious, i.e. composed of individuals producing gametes of both sexes (functionally hermaphrodite) and of individuals which do not produce male gametes (functionally female), the latter being present to a large proportion.

Other things being equal, there should be a selection against malesteriles, since these plants transmit genes through only one sex of gamete. Since a large number of such plants are found in natural populations of $T$. vulgaris, and of other gynodioecious species, they must possess some compensatory advantage. The magnitude of the advantage might be expected to depend on the environmental conditions.

Thyme offers the following advantages as material for the study of gynodioecy:

1. Individual plants generally bear only one kind of flowers (either hermaphrodite or female).

2. Plants are usually distinct, and do not grow into one another, thus allowing exact determinations of the frequency of male-steriles to be made.

3. The frequency of male-sterile individuals ranges from below 10 per cent to more than 90 per cent in different populations (Dommée, 1976).

4. Vegetative propagation is possible.

Since 1967 we have been trying to relate variation in the frequency of male-sterility to variation in the environment. Three theories have been 
put forward to explain polymorphic male sterility in plants. Lewis (1941) suggested that the male-sterile type might have a higher fertility as female than the male-fertiles. In his early work (1877) Darwin demonstrated such a higher seed production in male-sterile plants of thyme. Similar results have been found in this laboratory (Assouad, 1972; Dommée, 1973) but the differences are not great enough between the two kinds of individuals to account for the fixation of male-sterility genes in the population. Jain (1968) made a model assuming that the alleles which determine the male-sterility show overdominance in fitness and are thus maintained polymorphic. However, no overdominance effect has been demonstrated for male-sterility genes. Finally, Valdeyron et al. (1973) suggested that the male-sterile plants, which are obligatorily outbred, may produce superior offspring to those of the male-fertiles, whose offspring may exhibit inbreeding depression. It is known that gynodioecious species are often insect-pollinated. Limitations of pollen production and distribution could therefore play a part in determining the fertility of the male-sterile plants since these must outcross (Lewis, 1941; Lloyd, 1974). This effect may prevent fixation of male-sterility alleles but does not account for their selective advantage in an initially hermaphrodite population.

To give a selective interpretation of gynodioecy, we therefore wish to answer the following question: is a high level of male-sterility in a population an outbreeding mechanism (Mather, 1940) or is the female fertility of the male-steriles higher than that of the male-fertile plants? Baker (1963) points out that the first of these explanations implies that the male-fertiles must be capable of selfing. A simulation model (Valdeyron et al., 1973) led us to the conclusion that a high rate of self-fertilisation of the male-fertiles would be necessary for the male-steriles to have an advantage, in the absence of any increase in their female fertility. A very high level of inbreeding depression is also required. This conclusion is consistent with the one obtained by Lloyd (1975) following a more general treatment.

The purpose of the present paper is to report the results of determinations of $s$, the rate of selfing of the male-fertile form of thyme in the natural environment.

\section{MAterial AND MEthods}

\section{(i) General method}

We assume that a fraction $s$ of the ovules of male-fertile plants is selffertilised, the remainder being panmictically fertilised and that the malesteriles are fertilised panmictically by the pollen from the male-fertiles. If, in the pollen of a given population, a recessive marker allele, $r$, has a frequency $a$, the proportion of $r r$ individuals among the progeny of male-sterile $r r$ homozygotes is $a$. The proportion of $r r$ among the progeny of $r r$ male-fertile individuals is:

$$
b=s+a(1-s)
$$

which gives

$$
s=\frac{b-a}{1-a}
$$


If $a$ and $b$ are estimated independently, the variance of $s$ is given by

$$
\operatorname{var}(s)=\operatorname{var}(a)\left[\frac{\partial s}{\partial a}\right]^{2}+\operatorname{var}(b)\left[\frac{\partial s}{\partial a}\right]^{2}
$$

The value of $s$ can be measured most accurately when $a$ is zero. We therefore looked for populations with low frequencies of the dominant allele at the marker locus. Homozygous $r r$ plants were implanted in such populations at distances which minimise pollen transfer between implanted individuals.

\section{(ii) The markers}

We used as markers genes involved in the determination of the "chemotype" or composition of the essential oil of the plant. The existence of stable chemotypes in natural population of thyme has been demonstrated by Passet (1971) and Granger and Passet (1973). In the work described in the present paper, two of the chemotype loci (Vernet, 1976, 1977) were used. The first locus is called $C$. A recessive allele $c^{t}$ gives plants having predominantly thymol, whereas the dominant allele $C$ gives the carvacrol chemotype. These two compounds are phenolic isomers. The second locus, $L$, determines the presence $(L /-)$ or absence $(l l)$ of linalol; this locus is epistatic on the $C$ locus, so that $l l c^{t} c^{t}$ is the genotype of the thymol chemotype, $l l C G$ or $l l C c^{t}$ has carvacrol and the genotypes carrying at least one $L$ allele have linalol. The genetics of the other chemotypes that are found in thyme is not yet fully understood.

The chemotype is determined, using one leaf of the plant to be analysed, by pyrolysis in a nitrogen current and vapour phase chromatography on a Giravion Doran (Girdel 75-FD-2) chromatograph; 88 analyses can be completed in 1 day (Gouyon $e t$ al., in press).

Genetic studies on the markers give normal Mendelian ratios (Vernet, 1977) so that selective effects are unlikely to cause any bias in the results of the progeny tests.

\section{(iii) The sites}

Test plants from two different populations were transplanted into populations at four sites (table 1). The six sites were all within a $40 \times 40 \mathrm{~km}$ square, the centre of which is about $35 \mathrm{~km} \mathrm{NW}$ of Montpellier. The populations at Viols le Fort and Les Chênes are homogenous for the carvacrol phenotype; over 100 plants from each of these localities have been tested. At Pic St Loup many observations made over the whole area indicated that this population is also fixed for the same chemotype. At Le Vigan, there were various non-phenolic chemotypes (about 88 per cent linalol, 8 per cent alpha-terpineol and 12 per cent thuyanol-4). The genotype at the first three sites was therefore mainly $l l C C$; at Le Vigan the population was nearly all $L L c^{t} c^{t}$ (irrespective of genes for other non-phenolic chemotypes). At all sites, thymol plants (of genotype $l l c^{t} c^{t}$ ) are therefore suitable testers. 
TABLE 1

Description of the sites

\begin{tabular}{|c|c|c|c|c|c|}
\hline \multirow[b]{2}{*}{ Site } & \multirow{2}{*}{$\begin{array}{l}\text { Altitude } \\
(\mathrm{m})\end{array}$} & \multirow{2}{*}{$\begin{array}{l}\text { Predominant } \\
\text { chemotype }\end{array}$} & \multicolumn{2}{|c|}{$\begin{array}{l}\text { No. of } \\
\text { testers }\end{array}$} & \multirow[b]{2}{*}{ Short description of the site } \\
\hline & & & 우 & ళ̧ & \\
\hline Les Chênes & 234 & Carvacrol & 10 & 11 & $\begin{array}{c}\text { Flat carstic area (garrigue). } \\
\text { Quercus ilex and Q.pubescens }\end{array}$ \\
\hline Pic St Loup & 320 & Carvacrol & 1 & 4 & S. aspect. Q.ilex \\
\hline Viols le Fort & 290 & Carvacrol & 0 & 3 & Dolomitic sand. Flat. Q.ilex \\
\hline Le Vigan & 542 & Linalol & 7 & 11 & $\begin{array}{l}\text { W. aspect. } Q . \text { pubescens and } \\
\text { Castanea vulgaris }\end{array}$ \\
\hline Pompignan & 280 & Thymol & $-\cdots$ & - & $\begin{array}{l}Q . \text { ilex wood. Strongly } \mathrm{S} \\
\text { sloping. }\end{array}$ \\
\hline Le Coulet & 610 & $\begin{array}{l}\text { Linalol and } \\
\text { thymol }\end{array}$ & -- & --- & Grass cover. Bromus erectus \\
\hline
\end{tabular}

(iv) The transplants

The test plants were taken from Pompignan (male-sterile frequency: 5-15 per cent) and Le Coulet (85-90 per cent). Some of them were vegetatively reproduced before transplanting, in order to obtain some information on intra-genotypic variations in selfing rate.

The test plants were implanted at $20 \mathrm{~m}$ distance from each other. This distance was chosen after observations of the behaviour of the bees; these insects, which are apparently almost the only pollinators of thyme, do not transfer pollen for more than $10 \mathrm{~m}$ (Assouad, 1972). The plants were marked by attaching a plastic tag. As many transplants as possible were made during the wet season; it was nevertheless necessary to water the plants repeatedly during the first year.

\section{(v) Progeny tests}

Fruits were gathered at the end of June. In 1975, two collections were made, at an interval of 2 weeks, so as to limit losses of seeds and to investigate possible changes in the rate of selfing during pollination period. The number of fruits collected was usually recorded, so that estimates of the proportion of viable ovules of individual plants could be made.

The seeds were sown in the greenhouse in summer, and young seedlings were ready for analysis in the autumn. The analysis of the Le Vigan population, however, was done in the following spring, because the $L$ allele is not expressed before 3 to 4 months.

\section{Results}

\section{(i) Progenies of male-sterile plants}

Table 2 shows the results from the male-sterile plants. These data confirm the earlier results for the genotypes of the populations, at the chemotype loci. 
TABLE 2

Progeny of male-sterile testers

\begin{tabular}{clcc} 
Site & Year* & No. seedlings & $\%$ recessive \\
Les Chênes & 1973 & 60 & 5 \\
& 1974 & 119 & 1 \\
& 1975 & 248 & 3 \\
Le Vigan & 1974 & 36 & 0 \\
& 1975 & & \\
& 1st coll. & 357 & 4 \\
& 2nd coll. & 386 & 4 \\
& \multicolumn{2}{c}{ * See text. }
\end{tabular}

At Les Chênes, for example, we obtained a total of eleven $c^{l} c^{l}$ among 427 progeny from test plants, giving an estimate of a little less than 3 per cent for $a$. This gives an expected frequency of homozygotes of about $l$ in 1000 for a panmictic population-a rather likely figure.

In the data from 1973, three $c^{t} c^{t}$ were obtained among the 60 offspring analysed. These were obtained from three male-sterile plants, when there was no male-fertile tester implanted. Since 1974 and 1975 figures are not higher (actually, they are even lower), it appears that, in our conditions ( $20 \mathrm{~m}$ between implants), the implantation of a male-fertile individual does not interfere with the results obtained on neighbouring implants.

Similar results were obtained at Le Vigan. Here, the recessive marker is $l$, which is also present at a frequency of $0 \cdot 03$. The $C$ gene is very rare in this relatively northern population.

\section{(ii) Progeny of male-fertile plants}

Table 3 shows the results for each of the four stations and each of the 2 years. For 1975, the results of the two collections (1, early; 2, late), for the plants for which these are separately available, are also given.

\section{Conclusions AND discussion}

The data in table 3 gives estimates of the selfing rate $s$ (see section 2 (i)) of $0.358 \pm 0.019$ for Les Chênes and of $0.099 \pm 0.019$ for Le Vigan. If we admit that the estimation of the frequency of the recessive marker at Les Chênes is valid for Viols le Fort and Pic St Loup (see section 2 (iii)), the estimated values of $s$ are $0.487 \pm 0.048$ and $0.348 \pm 0.029$ for the two sites, respectively. The estimated value of the overall mean for the whole experiment would be $0.322 \pm 0.013$.

Due to losses of testers between 1974 and 1975 and to several other accidents, only seven plants (five at Les Chênes and two at Le Vigan) gave valid results for both years. The correlation coefficient is good $(r=0 \cdot 88$, significant at the 0.01 level); this indicates that a given plant in a given situation has a rather constant rate of selfing, from one year to the next.

The individual results are highly variable from one plant to another: the figures for $b$ extend from zero to $0 \cdot 79$. After a first examination of the detailed situation of each male-fertile tester (density of thyme plants around 
it, proximity of other male-fertile individuals, nature of plants of other species etc.) it seems that the main cause of variation might well be the availability of outside pollen in the first few metres around the testers, but other causes, such as ecotypic differences in origin of testers, cannot be excluded.

The influence of the environment is substantiated by the comparison between individuals of the same clone. For instance, four individuals resulting from the vegetative propagation of the C8 plant (from Le Coulet) were planted; one of the four, at Le Vigan, gave 4 per cent homozygotes in 71 seedlings while the three others, at Les Chênes, gave a total of 299 seedlings, of which 26 per cent were homozygotes (results for 1975 only).

TABle 3

Progeny of male-fertile testers

$\begin{array}{cccc}\text { Site } & \text { Year* } & \text { No. seedlings } & \text { \% recessive } \\ \text { Les Chênes } & 1974 & 78 & 21 \\ & 1975 & 642 & 40 \\ & \text { 1st coll. } & 233 & 59 \\ & \text { 2nd coll. } & 82 & 45 \\ \text { Viols le Fort } & 1975 & 114 & 50 \\ & \text { 1st coll. } & 75 & 64 \\ & \text { 2nd coll. } & 31 & 19 \\ \text { Pic St Loup } & \text { 1975 } & 307 & 36 \\ & \text { 1st coll. } & 109 & 44 \\ & \text { 2nd coll. } & 85 & 28 \\ \text { Le Vigan } & \text { 1974 } & 78 & 32 \\ & \text { 1975 } & 299 & 8 \\ & \text { 1st coll. } & 137 & 6 \\ & \text { 2nd coll. } & 96 & 10 \\ & & & \end{array}$

It might be useful to consider the values of $b$ (very close to $s$ ) given in table 3 for the two collections in 1975. It seems obvious that in the three first sites, where the rate of selfing is rather high, it is also higher in the first part of the flowering period, while this is not true at Le Vigan, where crossing is more frequent, as a whole. Le Vigan, on the slope of the Cevennes mountains, at an altitude of $542 \mathrm{~m}$, is ecologically separated from the three other sites, which are lower in altitude and nearer to the sea. The density of thyme plants is relatively higher and frequency of male-fertiles definitely higher at Le Vigan (2.1 plants by square metre and 54 per cent malefertiles at Le Vigan as against 1.3 and 34, respectively, at Les Chênes, for example). How these causes of variation possibly interact and affect the rate of selfing is not known but it would be a good working hypothesis to assume that the activity of the pollinators (bees) might play some part: the average temperature and, thercfore, the pollinating activity is likely to be higher at the end of the flowering period; it is not surprising if the rate of crossing also increases.

Our knowledge of many features of thyme biology has to be improved. 
Seed production is higher in male-steriles than in male-fertiles, but the difference is not great enough to maintain, as a unique factor, a gene for male-sterility at the high levels recorded in thyme populations. Inbreeding depression takes place but is variable according to individuals (Assouad et al., in preparation). The genetics of the male-sterility in thyme, which involves mendelian genes and cytoplasmic factors, is certainly complex (Assouad, 1972; Dommée, 1973). The significance of male sterility is, therefore, likely to be related to several factors. The above results, however, show that, at least in some populations, there is enough selfing in thyme to favour male-sterility at a rather high level as a mechanism for restricting inbreeding.

Acknowledgments.-We are specially grateful to Dr Brian Charlesworth (University of Sussex) for his co-operation in preparing this paper. Discussions and help from Professor Harper (Bangor) and Dr Lloyd (Christchurch) have also been much appreciated.

\section{REFERENCES}

AssovaD, M. w. 1972. Recherches sur la Génétique ecologique de Thymus vulgaris L. Etude expérimentale du polymorphisme sexuel. Thèse de Doctorat ès-Sciences, C.N.R.S., A.O. 7505, Montpellier, p. 224.

ASSOUAD, M. W., DOMmÉE, B., LUMARET, R. AND VALDEYron, G. Reproductive capacities in the sexual forms of the gynodioecious species Thymus vulgaris L. (in preparation).

BAKER, H. G. 1963. Evolutionary mechanisms in pollination biology. Science, 139, 877-883. DARwin, C. 1877. The Different Forms of Flowers on Plants of the Same Species. Murray, London.

ромме́E, в. 1973. Recherches sur la Génétique ecologique de Thymus vulgaris L. Déterminisme génétique et répartition écologique des formes sexuelles. Thèse de Doctorat ès-Sciences, G.N.R.S., A.O. 8635, Montpellier, p. 129.

роммÉE, в. 1976. La stérilité mâle chez Thymus vulgaris $\mathrm{L}$ : répartition écologique dans la région méditerranéenne française. C.R. Ac. Sc. Paris, $282 \mathrm{D}, 65-68$.

GOUYON, P. H., JAOUL, R., MALAdIERE, H., MILHOMME, H. AND VERNET, P. Introduction automatique d'échantillons solides dans un pyrolyseur (in press).

GRANGer, R. AND PASSET, J. 1973. Thymus vulgaris spontané de France: races chimiques et chémotaxonomie. Phytochemistry, 12, 1683-1691.

JAIN, s. k. 1968. Gynodioecy in Origanum vulgare: computer simulation of a model. Nature, 217, 764-765.

LEWIS, D. 1941. Male-sterility in natural populations of hermaphrodite plants: the equilibrium between females and hermaphrodites to be expected with different types of inheritance. Nere Phytol., 40, 56-63.

LLOYD, D. G. 1974. Theoretical sex ratios of dioecious and gynodioecious angiosperms. Heredity, 32, 11-34.

LLOYD, D. G. 1975. The maintenance of gynodioecy and androdioecy in angiosperms. Genetica, $45(3), 1-15$.

MATHER, x. 1940. Outbreeding and separation of sexes. Nature, 145, 494-486.

PASSET, J. 1971. Thymus vulgaris L.: chémotaxonomie et biogénèse monoterpénique. Thèse de Doctorat en Pharmacie, Montpellier, p. 153.

VALDEYRON, G., DOMMÉE, B. AND VALDEYRON, A. 1973. Gynodioecy: another computer simulation model. Amer. Natur., 107, 454-459.

vernet, P. 1976. Analyse génétique et écologique de la variabilité de l'essence de Thymus vulgaris L. (Labiée). Thèse de Doctorat ès-Sciences, C.N.R.S., A.O. 13224, Montpellier, p. 51 .

VERNET, P. 1977. Les variations de composition de l'essence de Thymus vulgaris L.: mode de transmission héréditaire de trois terpènes (le thymol, le carvacrol et le linalol). C.R. Ac. Sc. Paris, D (in press). 